\title{
COMMENTARY
}

\section{Progesterone and breast cancer pathogenesis}

\author{
Avrum Z Bluming \\ Emeritus Clinical Professor of Medicine, University of Southern California, Los Angeles, California, USA
}

Correspondence should be addressed to A Z Bluming: avrumzbluming@yahoo.com

In their recent review, 'Progesterone and progesterone receptors in breast cancer: past, present, future' (published in the July 2020 issue of Journal of Molecular Endocrinology, volume 65, pages T49-T63), Horwitz \& Sartorius evaluate the role of progesterone in the development and course of breast cancer. They report that in the normal breast, progesterone promotes differentiation at the expense of growth, and they state that in the absence of a chemical carcinogen, it is difficult, if not impossible, to cause breast cancer with progesterone. They further note that multiple clinical studies found that progestins were as effective as tamoxifen at improving progression-free survival of ER+ breast cancer, and they conclude by stressing the need to debunk the notion that progesterone causes breast cancer (Horwitz \& Sartorius 2020).

Their conclusion, they note, is contradicted by two large studies, The Women's Health Initiative (WHI) (Rossouw et al. 2002, Chlebowski et al. 2010) and The Million Women Study (MWS) (Beral et al. 2011). While these studies have indeed concluded that combination oestrogen/progestin does increase the risk of breast cancer, their reported results have been seriously challenged. In the WHI, the risk of breast cancer among women randomised to oestrogen alone (consistently reported by them as showing no increased risk) was the same as the risk of breast cancer among women randomised to the combination of oestrogen and progestin (HRT) (reported as showing an increased risk). The differing results were due to the low risk noted in the HRT control group. This lowered risk appears to have resulted from including within that placebo group women who had taken oestrogen prior to joining the study, and who were randomly assigned to the placebo arm. When the risk was recalculated after these women were excluded, the increased risk observed among those randomly assigned to HRT had disappeared (Hodis \& Sarrel 2018). The senior authors, aware of this criticism, have continued to publish updates without commenting on nor correcting this critical misinterpretation.

The Million Women Study consisted of only two questionnaires separated by about 3 years and sent to over a million women (Beral \& Million Women Study Collaborators 2003). In spite of the grandiose title, only $44 \%$ of the sample responded to both surveys. A summary of the negative criticisms of that paper is summarised subsequently:

- The total incidence of breast cancer in the study, among all the women surveyed, was $1.4 \%$. Of that $1.4 \%$, the increased risk of breast cancer was identified only in current hormone users but not in past users - even if past use had exceeded 15 years. The authors never explain nor offer a biologic rationale for why current use is harmful and past use is not.

- The average time from beginning therapy to diagnosis of breast cancer was brief (1.2 years), suggesting to clinicians that, in many cases, breast cancer had probably been present, but unidentified, before the women entered the study; the women who agreed to fill out the original questionnaire may thus have been concerned about a problem in the breast, prompting their participation. The study appears to have been selecting this population with, not surprisingly, a median time from diagnosis to death from breast cancer of only 1.7 years.

- In the paper cited by Horwitz \& Sartorius, eight years after the original Million Women Study report, the same investigators reported an admittedly small 
increased risk of breast cancer seen among women taking hormones, which was found only among those who started within five years of reaching menopause. For those starting hormones more than five years after a final menstrual period, the incidence of breast cancer was the same as that found among never users (Chlebowski et al. 2010). They offer no rationale for this finding. The authors' reliance on questionably generated numbers to the exclusion of biologic plausibility raises serious questions about the reliability of the conclusions they present.

- In 2012, Nick Panay, Chair of the British Menopause Society, wrote the following about the Million Women Study: 'I believe the use of statistics in this study is intimidating to most readers, and possibly to editors as well. I can't help but feel that these authors decide what conclusions they want to publish, and use their data to construct the desired conclusion' (Panay 2012).

Another study was published by the MWS investigators in 2019 (Collaborative Group on Hormonal Factors in Breast Cancer 2019). They reportedly analysed the data records of 108,647 postmenopausal breast cancer patients collected from dozens of previously published reports as well as unpublished data sets, and compared each patient with up to four randomly selected matched controls without a breast cancer diagnosis. A small increase among those who were taking HRT was identified. In the accompanying editorial, Joanne Katsopoulos of the Women's College Research Institute in Toronto, wrote: 'The complexity of the study design makes it difficult to appraise the results and most of us will take the results on face value' (Kotsopoulos 2019). Read that statement again. When researchers dazzle readers with an avalanche of findings that require other professionals to 'take the results on face value', something is very wrong. It is the researchers' job to make their data available - and readable - so that the data can be assessed independently. And yet Katsopoulos, while admitting it was 'difficult to appraise the results', apparently had no qualms titling her editorial 'Definitive evidence for breast cancer'. Definitive?

The role of progesterone in the pathogenesis of breast cancer obviously requires further investigation.
Future studies should not be misled by misinterpreted data and the misleading conclusions of the WHI and the MWS.

\section{Declaration of interest}

The author declares that there is no conflict of interest that could be perceived as prejudicing the impartiality of this commentary.

\section{Funding}

This work did not receive any specific grant from any funding agency in the public, commercial or not-for-profit sector.

\section{References}

Beral V \& Million Women Study Collaborators 2003 Breast cancer and hormone-replacement therapy in the Million Women Study. Lancet 362 419-427. (https://doi.org/10.1016/s0140-6736(03)14065-2)

Beral V, Reeves G, Bull D, Green J \& Million Women Study Collaborators 2011 Breast cancer risk in relation to the interval between menopause and starting hormone therapy. Journal of the National Cancer Institute 103 296-305. (https://doi.org/10.1093/ jnci/djq527)

Chlebowski RT, Anderson GL, Gass M, Lane DS, Aragaki AK, Kuller LH, Manson JE, Stefanick ML, Ockene J, Sarto GE, et al. 2010 Estrogen plus progestin and breast cancer incidence and mortality in postmenopausal women. JAMA 304 1684-1692. (https://doi. org/10.1001/jama.2010.1500)

Collaborative Group on Hormonal Factors in Breast Cancer 2019 Type and timing of menopausal hormone therapy in breast cancer risk: individual participant meta-analysis of the worldwide epidemiological evidence. Lancet 394 1159-1168. (https://doi. org/10.1016/S0140-6736(19)31709-X)

Hodis HN \& Sarrel PM 2018 Menopausal hormone therapy and breast cancer: what is the evidence from randomized trials? Climacteric 21 521-528. (https://doi.org/10.1080/13697137.2018. 1514008)

Horwitz KB \& Sartorius CA 202090 YEARS OF PROGESTERONE: Progesterone and progesterone receptors in breast cancer: past, present, future. Journal of Molecular Endocrinology 65 T49-T63. (https://doi.org/10.1530/JME-20-0104)

Kotsopoulos J 2019 Menopausal hormones: definitive evidence for breast cancer. Lancet 394 1116-1118. (https://doi.org/10.1016/S01406736(19)31901-4)

Panay N 2012 Commentary regarding recent Million Women Study critique and subsequent publicity. Menopause International 18 33-35. (https://doi.org/10.1258/mi.2012.012006)

Rossouw JE, Anderson GL, Prentice RL, LaCroix AZ, Kooperberg C, Stefanick ML, Jackson RD, Beresford SA, Howard BV, Johnson KC, et al. 2002 Risks and benefits of estrogen plus progestin in healthy postmenopausal women: principal results from the Women's Health Initiative randomized controlled trial. JAMA 288 321-333. (https:// doi.org/10.1001/jama.288.3.321)

Received in final form 16 September 2020

Accepted 27 October 2020

Accepted Manuscript published online 28 October 2020
(C) 2021 Society for Endocrinology Published by Bioscientifica Ltd. Printed in Great Britain 